\title{
Crítica genética: non in tempore, sed cum tempore
}

* Raul Antelo / Universidade Federal de Santa Catarina - CNPq

antelo@iaccess.com.br

\section{Resumen}

A cultura contemporânea está atravessada por uma experiência de relativa pós-finitude. No entanto, costumamos abordar cada obra literária antes mesmo de ela ter sido dada como pronta, ao lermos notas, borradores, correspondências que lhe dão sentido. Nos últimos anos, tenho trabalhado numa abordagem genética, arqui-filológica, que se situa, portanto, em um limiar, um confim metodológico, o do rastro, que nos abre uma concepção de tempo iminente.

Comecemos, a título de exemplo canônico, por um clássico de Borges, «Pierre Menard, author of the Quixote». Esse conto nos propóe um tempo de regressáo infinita em que encontramos os grandes temas modernistas: leitura, memória, o vínculo íntimo entre história e sentimento, o valor do reconhecimento e acristalização desses tópicos na leitura da história tal como figurada no texto.

Palavras chave: Arqui-filologia $\cdot$ eterno retorno •

história

\section{Abstract}

Contemporary culture is permeated by a feeling of relative after finitude. Nonetheless, we generally approach each literary work from before it is even considered ready, as we read notes, drafts, and letters that help to make sense out of it. In recent years, I have worked with a genetic, archiphilological approach, set, thus, at a threshold, a methodological frontier, that of the path or arcade, which leads us to a concept of imminent time. As a canonical example, let's begin with a classic by Borges, «Pierre Menard, author of the Quixote». This short story creates a time of infinite regression where we find the great modernist themes: reading, memory, the intimate linkage of form to emotion, the value of recognition, and the crystallization of all these topics in the reading of history as figured in the text.

Key words: Archi-philology • infinite regression • History 